\title{
Productivity Enhancement of Green Gram by Cluster Frontline Demonstrations in Mahabubabad District of Telangana, India
}

\author{
T. Chaitanya*, M. Sunil Kumar, A. Rammulamma and A. Sarala Kumari \\ Krishi Vigyan Kendra, Malyal, Mahabubabad district, Telangana state, \\ Professor Jayashankhar Telangana State Agricultural University, \\ Hyderabad - 500030, India \\ *Corresponding author
}

\begin{tabular}{|l|}
\hline K e y w o r d s \\
CFLDs, green \\
gram, Grain yield, \\
Benefit cost ratio.
\end{tabular}

\section{A B S T R A C T}

Cluster frontline demonstrations (CFLDs) on greengram was conducted by Krishi Vigyan Kendra, Malyal in villages namely Redyala, Gudur, Gouraram Mulakalapalli, Apparajupalli of Mahabubabad district of Telangana state during the rabi season of 20162017, 2017-18 and 2018-19 respectively. The results revealed that the variety MGG-347 with seed treatment (imidacloprid@2ml/kg + carbendazim@1g/kg +Rhizobium spp@ $25 \mathrm{~g} / \mathrm{kg}$ ) + plant protection (Yellow sticky trap + Neem oil + insecticide) nutrient and weed management recorded average highest yield of $1397 \mathrm{~kg} / \mathrm{ha}(2016-17)$ against the farmers practice of $1157 \mathrm{~kg} / \mathrm{ha}$. The maximum gross returns of Rs. $82500 /-$ and net returns of Rs. 57925/- during the year 2017-18 and minimum of Rs. 68000/- and net returns of Rs. 45500/- during the year 2018-19 were obtained due to variation in MSP sale rates as declared by GOI. The study revealed that an extension gap of 140 to $350 \mathrm{~kg} / \mathrm{ha}$ was found between demonstrated technology and farmer's practice and on average basis the extension gap was $240 \mathrm{~kg} / \mathrm{ha}$. The study further exhibited a wide technology gap during different years. It was lowest (40 kg/ha) during 2016-17 and highest (140 kg/ha) during 2018-19. The average technology gap of all the years was $103 \mathrm{~kg} / \mathrm{ha}$. The difference in technology gap in different years was due to better performance of recommended varieties with different interventions and more feasibility of recommended technologies during the course of study. Similarly, the technology index for all demonstrations in the study was in accordance with technology gap. It can be concluded that the green gram production could be enhanced by encouraging the farmers through adoption of recommended technologies which were followed in the Cluster Front Line Demonstrations. Further, it was found that the adoption of improved technologies significantly increased the yield and net returns to the farmers. Hence, there is a need to disseminate the improved technologies among the farmers with effective extension methods like trainings and demonstrations.

\section{Introduction}

India is the largest producer, consumer and importer of pulses in the world. It accounts for 33 per cent of world area and 22 per cent of the total world production of pulses (Sandhu and Dhaliwal, 2016). Pulses are good and cheaper source of protein, which indicate 
the great importance of pulses in our daily food habits. Pulse crops have ability to fix the atmospheric nitrogen and addition of organic matter to soil, which are important factors to maintain soil fertility (Kumar and Singh, 2014). Pulses are major sources of proteins among the vegetarians in India and complement the staple cereals in the diets with proteins, essential amino acids, vitamins and minerals. They contain 22-24 per cent protein, which is almost twice the protein in wheat and thrice that of rice. Pulses contribute 11 per cent of the total intake of proteins in India (Reddy, 2010).

National Food Security Mission (NFSM) was launched in 2007-08 to increase the production of rice, wheat and pulses by 10,8 and 2 million tonnes, respectively by the end of 11th Plan through area expansion and productivity enhancement; restoring soil fertility and productivity; creating employment opportunities; and enhancing farm level economy. The Mission was continued during 12th Plan with new target of additional production of 25 million tones. The basic strategy of the Mission is to promote and extend improved technologies, i.e., seed, micro-nutrients, soil amendments, integrated pest management, farm machinery and implements, irrigation devices along with capacity building of farmers.

The major interventions/activities covered under NFSM include cluster demonstrations of rice, wheat, pulses and coarse cereals, distribution of improved varieties/hybrid seeds, need based inputs, resource conservation techniques / energy management, efficient water / application tools, cropping system based trainings and local initiatives; award for best performing districts etc. (Department of Agriculture, Cooperation \& Farmers Welfare, Annual Report 2017-18). Over the last few years, the area and production of pulses in Telangana
State increased tremendously due to inception of Cluster Front Line Demonstration concept at farmers' field. Front Line demonstration is a long term educational activity conducted in a systematic manner at farmers' fields to show worth of a new technology on "Seeing is Believing" principle. Traditional or farmer's practices are no longer sustainable towards pulse production as it shows huge gap in yields in comparison to scientific production technologies. Constant efforts are needed to bridge this gap through demonstration of improved production technologies.

Over a period of time, a number of improved pulse varieties and production technologies have been developed, but full potential of these varieties and technologies could not be exploited due to lack of awareness on varieties, low rate of adoption by the farmers leading to low yields. Pulses are the major source of protein compared to cereals, oilseeds and other crops. Pulse production is mostly from the crop raised under rain-fed conditions. Cultivation of pulses in marginal lands, limited area of pulses under irrigated conditions, limited high yielding varieties, pests and diseases and processing loss up to 6-8 per cent are some of the problems for the stagnation of pulse production over decades. Thus, factors limiting the productivity cannot be overlooked. Research and extension programmes need to be diverted to produce value additive pulses.

\section{Materials and Methods}

The present investigation of cluster frontline demonstrations (CFLDs) on greengram was conducted by Krishi Vigyan Kendra, Malyal in villages namely Redyala and Gudur (201617), Gouraram (2017-18), Mulakalapalli and Apparajupalli (2018-2019) of Mahabubabad District of Telangana state during the rabi season. The demonstration was conducted in 
an area of 20 ha in every year, five locations against local variety in three years. 110 demonstrations in 60 ha (2016-17 to 2018-19) were conducted with active participation of farmers to demonstrate the improved technologies of Green gram in different villages so as to establish production potentials and expand the area under the crop in the district. Present study with respect to CFLDs and farmers' practices are given in Table 1.The soils in selected villages were sandy loam. Farmers were trained to follow the package of practices for green gram cultivation as recommended by the State Agricultural University and need based input materials provided to the farmers (Table 2).

Every year 20 hectares were taken for the demonstration of technologies in green gram crop along with farmers practice as check plot. Pre-sowing trainings were organized involving the selected farmers on the crops. Selected green gram variety, MGG-347 was high yielding (12.5 to $15 q /$ ha), tolerant to yellow mosaic virus and suitable to all seasons. Critical inputs along with technologies like seed treatment, fertilizer application, water and weed management, integrated pest and disease management etc., were demonstrated at every stage of the crop with appropriate trainings. Regular visit by the scientist helped in proper execution of trials as well as collecting farmer's opinion on the demonstrated varieties. The performance of the varieties in the trials was judged visually as well as quantitatively by farmers themselves. Field days were conducted involving demonstration holding farmers, neighboring farmers, Scientists from University, Officials from Department of Agriculture and local extension functionaries to demonstrate the superiority of the technology. Crop yields were recorded from the demonstration and check plots at the time of harvest to identify the yield gaps between demo and check plots.

Table.1 Particulars showing the details of green gram grown under CFLD and farmers' practice

\begin{tabular}{|l|l|l|}
\hline Operation & Existing practice & Improved practices demonstrated \\
\hline Line sowing & Broad casting of seed & $\begin{array}{l}\text { Spacing } 30 \mathrm{~cm} \text { between rows and } 10 \mathrm{~cm} \\
\text { between plants. }\end{array}$ \\
\hline Seed treatment & MGG-295 & MGG-347 \\
\hline $\begin{array}{l}\text { Yellow mosaic } \\
\text { virus tolerance }\end{array}$ & No tolerance & $\begin{array}{l}\text { Seed treatment with Imidacloprid @ 2m1/kg + } \\
\text { Carbendazim @ 1g/kg +Rhizobium spp @ } \\
25 \mathrm{~g} / \mathrm{kg} \text { of seed }\end{array}$ \\
\hline $\begin{array}{l}\text { Weed } \\
\text { management }\end{array}$ & No Weed management & $\begin{array}{l}\text { Tolerant variety } \\
\text { Weeds control by using herbicide }\end{array}$ \\
\hline $\begin{array}{l}\text { Nutrient } \\
\text { management }\end{array}$ & $\begin{array}{l}\text { No fertilizer application } \\
\text { pre-emergence treatment for effective control } \\
\text { of weeds within two days after sowing. }\end{array}$ \\
\hline Whole package & $\begin{array}{l}\text { Farmers are cultivating } \\
\text { Recommended dose of fertilizers }\end{array}$ \\
$\begin{array}{l}\text { the greengram crop } \\
\text { without adoption of any } \\
\text { improved technology }\end{array}$ & $\begin{array}{l}\text { All the crop (production and protection) } \\
\text { management practices as per the package of } \\
\text { practices for rabi crop by PJTSAU, } \\
\text { Hyderabad were followed for raising the crop }\end{array}$ \\
\hline
\end{tabular}


Table.2 Details of need based inputs of green gram used in CFLD

\begin{tabular}{|c|c|c|c|c|c|c|}
\hline Cluster & $\begin{array}{l}\text { Number of } \\
\text { demonstrations }\end{array}$ & $\begin{array}{l}\text { Area in } \\
\text { hectares }\end{array}$ & $\begin{array}{l}\text { Varie } \\
\text { ty }\end{array}$ & Year & Technology Demonstrated & $\begin{array}{l}\text { Need based } \\
\text { inputs }\end{array}$ \\
\hline Redyala, Gudur & 40 & 20 & $\begin{array}{l}\text { MGG- } \\
347\end{array}$ & $\begin{array}{l}2016 \\
-17\end{array}$ & \multirow{3}{*}{$\begin{array}{l}\text { - High yielding variety- } \\
\text { MGG-347 } \\
\text { - Seed treatment with } \\
\text { Imidacloprid } \\
\text { @ } 2 \mathrm{ml} / \mathrm{kg}+\text { carbendazim } \\
@ 1 \mathrm{~g} / \mathrm{kg}+\text { Rhizobium spp } \\
\text { @ } 25 \mathrm{~g} / \mathrm{kg} \text { of seed } \\
\text { - Fertilizer } \\
\text { recommendation based on } \\
\text { soil test results } \\
\text { - Yellow sticky trap @ } 10 \\
\text { Nos/acre } \\
\text { - Neem oil + insecticide }\end{array}$} & \multirow{3}{*}{$\begin{array}{l}\text { - Treated seed } \\
\text { - Rhizobium spp } \\
\text { - Yellow sticky } \\
\text { traps } \\
\text { - Neem oil } \\
\text { - Thiomethoxam } \\
\text { - Multi-K } \\
(13: 0: 45)\end{array}$} \\
\hline Gouraram & 25 & 20 & $\begin{array}{l}\text { MGG- } \\
347\end{array}$ & $\begin{array}{l}2017 \\
-18\end{array}$ & & \\
\hline $\begin{array}{l}\text { Mulakalapalli, } \\
\text { Apparajupalli }\end{array}$ & 45 & 20 & $\begin{array}{l}\text { MGG- } \\
347\end{array}$ & $\begin{array}{l}2018 \\
-19\end{array}$ & & \\
\hline
\end{tabular}

The data with respect to grain yield from FLD plots and from fields cultivated following local practices adopted by the farmers of the area were collected and evaluated. Potential yield was taken in to consideration on the basis of standard plant population (404440 plants/ ha) and average yield per plant 22.5 $\mathrm{g} /$ plant under recommended package of practices with $30 \times 10 \mathrm{~cm}$ crop geometry (Chandra, 2010). Different parameters as suggested by Yadav et al., (2004) was used for gap analysis, and calculating the economics. The details of different parameters and formula adopted for analysis are as under:

Extension gap $=$ Demonstration yield Farmers' practice yield

Technology gap = Potential yield Demonstration yield

Technology index $=\frac{\text { Potential yield }- \text { Demonstration yield }}{\text { Potential yield }} \times 100$

\section{Results and Discussion}

\section{Seed yield}

The productivity of green gram under improved production technology ranged between $1170-1620 \mathrm{~kg} / \mathrm{ha}, 1000-1500 \mathrm{~kg} / \mathrm{ha}$ and $1190-1520 \mathrm{~kg} / \mathrm{ha}$ during the years 2016 $17,2017-18$ and 2018-19 respectively as against a yields of 1320,1020,1130 respectively under farmers' practice. In comparison to farmer's practice, there was an increase of 23,47 and 35 per cent in productivity of greengram under improved technologies during the years 2016-17, 201718 and 2018-19 respectively.

The difference in yield observed during different years was due to variation in available irrigation facility at different places, dissimilarities in soil fertility levels, pest and disease incidence, improper usage of manures and fertilizers. The increased grain yield with improved technologies was mainly because of line sowing, seed treatment, nutrient management and weed management. The findings were in line with Meena et al., (2012) and Meena and Dudi (2018).

\section{Economics}

Economic returns as a function of gain yield and MSP sale price varied during different years. The maximum gross returns of Rs. 
82500/- and net returns of Rs. 57925/- during the year 2017-18 and minimum of Rs. 68000/- and net returns of Rs. 45500/- during the year 2018-19 were obtained due to variation in cost of cultivation as labour charges increased year after year and MSP sale rates as declared by GOI. The higher additional returns and effective gain obtained under demonstrations could be due to improved technology, non-monetary factors, timely operations of crop cultivation and scientific monitoring and also sale of seed to other farmers as a seed. The lowest and highest benefit cost ratio were 2.4 and 3.4 in 2017-18 and 2016-17, respectively (Table 4) depends on produced grain yield and MSP sale rates. The results were in confirmity with the findings of front line demonstrations on pulses by Chaudhary (2012), Meena and Dudi (2018).

Table.3 Seed yield of green gram under FLD and FP

\begin{tabular}{|c|c|c|c|c|c|c|c|c|c|}
\hline \multirow[t]{2}{*}{ Year } & \multirow[t]{2}{*}{$\begin{array}{c}\text { Area } \\
\text { (ha) }\end{array}$} & \multirow[t]{2}{*}{$\begin{array}{c}\text { Demonstration } \\
\text { (No) }\end{array}$} & \multicolumn{3}{|c|}{$\begin{array}{l}\text { Yield obtained } \\
\text { (kg/ha) }\end{array}$} & \multicolumn{2}{|c|}{ Yield kg/ha } & \multirow{2}{*}{$\begin{array}{l}\text { Additional yield (kg/ } \\
\text { ha) over farmer's } \\
\text { practice }\end{array}$} & \multirow[t]{2}{*}{$\begin{array}{l}\text { Per cent } \\
\text { increase }\end{array}$} \\
\hline & & & Max. & Min. & Av. & Demo & FP & & \\
\hline 2016-17 & 20 ha & 40 & 1620 & 1170 & 1460 & 1620 & 1320 & 300 & 23 \\
\hline 2017-18 & 20 ha & 25 & 1500 & 1000 & 1370 & 1500 & 1020 & 480 & 47 \\
\hline 2018-19 & 20 ha & 45 & 1520 & 1190 & 1360 & 1520 & 1130 & 390 & 35 \\
\hline
\end{tabular}

Table.4 Economics of green gram under FLD and FP

\begin{tabular}{|c|c|c|c|c|c|c|c|c|c|}
\hline \multirow[t]{2}{*}{ Year } & \multirow[t]{2}{*}{ Variety } & \multicolumn{4}{|c|}{ Farmer's Existing plot } & \multicolumn{4}{|c|}{ Demonstration plot } \\
\hline & & $\begin{array}{l}\text { Gross } \\
\text { cost } \\
\text { (Rs./ha) }\end{array}$ & $\begin{array}{l}\text { Gross } \\
\text { return } \\
\text { (Rs./ha) }\end{array}$ & $\begin{array}{l}\text { Net } \\
\text { return } \\
\text { (Rs./ha) }\end{array}$ & $\begin{array}{l}\text { B:C } \\
\text { Ratio }\end{array}$ & $\begin{array}{l}\text { Gross } \\
\text { Cost } \\
\text { (Rs./ha) }\end{array}$ & $\begin{array}{l}\text { Gross } \\
\text { return } \\
\text { (Rs./ha) }\end{array}$ & $\begin{array}{l}\text { Net } \\
\text { return } \\
\text { (Rs./ha) }\end{array}$ & $\begin{array}{l}\text { B:C } \\
\text { ratio }\end{array}$ \\
\hline 2016-17 & MGG-347 & 14,500 & 59,040 & 44540 & $3: 1$ & 16,250 & 73,000 & 56750 & $3.4: 1$ \\
\hline 2017-18 & MGG-347 & 25,000 & 55,000 & 30,000 & $1.2: 1$ & 24,575 & 82,500 & 57925 & $2.4: 1$ \\
\hline 2018-19 & MGG-347 & 25000 & 56500 & 31500 & $2.2: 1$ & 22500 & 68000 & 45500 & $3.0: 1$ \\
\hline
\end{tabular}

\section{Performance of FLD}

Yield of frontline demonstration trials and potential yield of the crop was compared to estimate the yield gap further it was categorized into extension gap, technology gap and technology index. The extension gap and technology gap observed that it may be attributed due to dissimilarities in soil fertility levels, pest and disease incidence, improper usage of manures and fertilizers. Hence, to narrow down the yield gaps location specific technologies needs to be adopted.
The study (Table 4) revealed that an extension gap of 140 to $350 \mathrm{~kg} / \mathrm{ha}$ was found between demonstrated technology and farmers' practice and on average basis the extension gap was $240 \mathrm{~kg} / \mathrm{ha}$. The extension gap was highest (350 kg/ ha) during 2017-18 and lowest (140 kg/ha) during 2016-17. Such gap might be attributed to adoption of improved technology especially with high yielding new varieties sown in line with balanced nutrition, weed management and appropriate plant protection measures in demonstrations which 
resulted in higher grain yield than the traditional farmers' practices. The study further exhibited a wide technology gap during different years. It was lowest (40 $\mathrm{kg} / \mathrm{ha}$ ) during 2016-17 and highest (140 $\mathrm{kg} / \mathrm{ha}$ ) during 2018-19. The average technology gap of all the years was $103 \mathrm{~kg} / \mathrm{ha}$.

The difference in technology gap in different years was due to better performance of recommended varieties with different interventions and more feasibility of recommended technologies during the course of study. Similarly, the technology index for all demonstrations in the study was in accordance with technology gap. Higher technology index reflected the inadequate transfer of proven technology to growers and insufficient extension services for transfer of technology.

Hence, it can be inferred that the awareness and adoption of improved varieties with recommended scientific package of practices have increased during the study period. These findings were in the conformity of the results of study carried out by Chandra (2010), Meena and Singh (2017), Meena and Dudi (2018).

Table.5 Technological gap analysis of frontline demonstrations on green gram farmers' field

\begin{tabular}{|l|l|l|l|l|l|l|l|}
\hline Year & $\begin{array}{l}\text { Number of } \\
\text { FLDs }\end{array}$ & $\begin{array}{l}\text { Potential } \\
\text { yield } \\
\text { (kg/ha) }\end{array}$ & $\begin{array}{l}\text { FLD } \\
\text { yield } \\
(\mathbf{k g} / \mathbf{h a})\end{array}$ & $\begin{array}{l}\text { FP } \\
\text { yield } \\
(\mathbf{k g} / \mathbf{h a})\end{array}$ & $\begin{array}{l}\text { EG } \\
(\mathbf{k g} / \mathbf{h a})\end{array}$ & $\begin{array}{l}\text { TG } \\
(\mathbf{k g} / \mathbf{h a})\end{array}$ & $\begin{array}{l}\text { TI } \\
(\mathbf{k g} / \mathbf{h a})\end{array}$ \\
\hline $\mathbf{2 0 1 6 - 1 7}$ & 40 & $\mathbf{1 5 0 0}$ & 1460 & 1320 & $\mathbf{1 4 0}$ & $\mathbf{4 0}$ & $\mathbf{2 . 7}$ \\
\hline $\mathbf{2 0 1 7 - 1 8}$ & 25 & $\mathbf{1 5 0 0}$ & 1370 & 1020 & $\mathbf{3 5 0}$ & $\mathbf{1 3 0}$ & $\mathbf{8 . 7}$ \\
\hline $\mathbf{2 0 1 8}-19$ & 45 & $\mathbf{1 5 0 0}$ & 1360 & 1130 & $\mathbf{2 3 0}$ & $\mathbf{1 4 0}$ & $\mathbf{9 . 3}$ \\
\hline Average & & $\mathbf{1 5 0 0}$ & 1397 & 1157 & $\mathbf{2 4 0}$ & $\mathbf{1 0 3}$ & $\mathbf{6 . 9}$ \\
\hline
\end{tabular}

$\mathrm{EG}=$ Extension gap $; \mathrm{TG}=$ Technology gap; $\mathrm{TI}=$ Technology index; $\mathrm{FP}=$ Farmers practices

Sunderban, West Bengal. J Indian Soc

Costal Agril Res 28:12-15.

It may be concluded that the frontline demonstrations conducted on green gram at farmer's field revealed that the adoption of improved technologies significantly increased the yield as well as gross and net returns to the farmers. Hence, there is a need to disseminate the high yielding varieties with improved technologies among the farmers with effective extension methods like training and demonstrations. The farmer's should be encouraged to adopt the recommended package of practices for realizing higher returns.

\section{References}

Chandra G (2010). Evaluation of frontline demonstrations of greengram in
Chaudhary S (2012). Impact of Front Line Demonstration on Adoption of Improved Greengram Production Technology in Nagaur District of Rajasthan. M.Sc. Thesis, SKRAU, Bikaner.

Dayanand, Verma R K and Mahta S M (2012). Boosting the mustard production through front line demonstrations. Indian Res $J$ Ext Edu 12(3):121-123.

Department of Agriculture, Cooperation \& Farmers Welfare, Directorate of Pulses Development

Annual Report, 2017-18.

Kumar S and Singh R N (2014). Effect of vermicompost and Rhizobium application on productivity of 
Mungbean sown after wheat. $R A U$ Journal of Res 24(1-2): 26-28.

Meena M L and Aishwarya Dudi (2018). Increasing Greengram Production through Frontline Demonstrations under Rainfed Conditions of Rajasthan. J Krishi Vigyan 2018, 7(1): 144-148.

Meena M L and Singh D (2017). Technological and extension yield gaps in greengram in Pali district of Rajasthan, India. Legume Res 40(1):187-190.

Meena O P, Sharma K C, Meena R H and Mitharwal B S (2012). Technology transfer through FLDs on mung bean in semi-arid rgion of Rajasthan. Rajasthan
J Ext Edu 20:182-186.

Reddy A A ( 2010). Regional disparities in food habits and nutritional intake in Andhra Pradesh, India. Regional \& Sectoral Econ Stud 10 (2) :125-134.

Singh D and Meena M L (2011). Boosting seed spices production technology through front line demonstrations. Int $J$ Seed Spices 1(1):81-85.

Yadav D B, Kambhoj B K and Garg R B (2004). Increasing the productivity and profitability of sunflowers through frontline demonstrations in irrigated agro-ecosystem of eastern Haryana. Haryana J Agron 20 (1):33-35.

\section{How to cite this article:}

Chaitanya. T., M. Sunil Kumar, A. Rammulamma and Sarala Kumari, A. 2020. Productivity Enhancement of Green Gram by Cluster Frontline Demonstrations in Mahabubabad District of Telangana, India. Int.J.Curr.Microbiol.App.Sci. 9(02): 1492-1498. doi: https://doi.org/10.20546/ijcmas.2020.902.172 